\title{
The Concept of Stolby Nature Reserve in the Aspect of Linguoimageology
}

\author{
Irina V. Evseeva and Irina S. Zhmakina* \\ Siberian Federal University \\ Krasnoyarsk, Russian Federation
}

Received 30.07.2020, received in revised form 06.08.2020, accepted 10.12.2020

\begin{abstract}
The article examines the concept of Stolby Nature Reserve in the aspect of the theory of linguoimageology, the tasks of which include the study and the development of technologies for creating the image of someone / something through the use of linguistic means that effectively influence the creation of a positive image of an object.

The main purpose of this research is to model the image of a national park based on the exclusive properties of this object. In the course of the linguo-cognitive analysis of empirical material (publicistic texts about the reserve), the authors identified the components of the concept under study; built a frame-type model, providing for the conceptual, pragmatic and evaluative characteristics of the frame slots; determined the types of estimates that prevail in the texts about the reserve; found out the frequency of linguistic means - artistic tropes used for creating a positive image of the object under study.

The identified components of the concept of Stolby Nature Reserve were used as the basis for a frame model, the creation of which made it possible to highlight the gaps in the texts about the reserve.

The developed methodology can be applied to the analysis of the image component of other iconic regional sites. The study offers recommendations to improve the image of the nature reserve, which can be taken into account when creating new texts by the management of the reserve and travel agencies.
\end{abstract}

Keywords: linguoimageology, linguoconceptology, concept, image, Stolby Nature Reserve, a frame model of the concept, types of estimated values, linguistic expression means for the estimation.

Research area: philology.

Citation: Evseeva, I.V., Zhmakina, I.S. (2020). The concept of Stolby Nature Reserve in the aspect of linguoimageology. J. Sib. Fed. Univ. Humanit. Soc. Sci., 13(12), 1914-1926. DOI: 10.17516/19971370-0694.

\footnotetext{
(C) Siberian Federal University. All rights reserved

* Corresponding author E-mail address: ivevseeva@yandex.ru, irina.zhmakina97@yandex.ru ORCID: 0000-0003-0495-033X (Evseeva)
} 


\section{Introduction}

Among the topical social and humanitarian scientific studies of the last decade, there are works carried out within the framework of a new scientific direction that is imageology, initially focused on creating the image of a political leader (Volkova et al., 1997; Petrova, 2007; Potemkina, 2006; Frolova, 2007, etc.). Today, all kinds of business and tourist structures, organizations, political parties, sports clubs, countries, cities, nations, etc. are objects of imageology.

At present, much attention is paid to the issues of the formation and management a particular territory's image. The image is directly related to the concepts of success / failure, and a properly formed image, for example, of a region is one of the tools for a high quality of life of the population. As noted by I.A. Vasilenko, the largest cultural centres of the Russian Federation (St. Petersburg, Vladivostok, Novosibirsk, Nizhny Novgorod, Tomsk) have developed and adopted their own programs for the development of the image (Vasilenko, 2012).

Having studied the official portal of the Krasnoyarsk Territory, we did not find such a program. This does not mean that the regional administration does not pay attention to the image policy of the region. Thus, some documents touch the factors contributing to the formation of a positive image of the region (see, for example, the Concept of creating a school for gifted children at the Krasnoyarsk State Institute of Arts). However, it seems that there is no planned work in this direction.

A.V. Chepkasov noted that "the purpose of regional positioning is to highlight the key characteristics of the territory, to identify and sometimes create clear landmarks indicating its originality. Positioning a region, making it recognizable is possible only by promoting its local exclusive properties" (Chepkasov, 2018a: 36). In the light of the foregoing, we believe that it is relevant and pragmatically important (1) to identify exclusive objects in the region that can become image-forming in the light of the image policy of the city of Krasnoyarsk and the Krasnoyarsk Territory in general; (2) to develop an image model of the region as a whole and image models of specific types of iconic objects (cultural and historical heritage sites, natural, economic, sports sites, etc.), in which the linguistic parameter occupies a leading position.

In this study, from the standpoint of linguoimageology, we will pay attention to one of the landmark objects of Krasnoyarsk and the Krasnoyarsk Territory - Stolby Nature Reserve (hereinafter Stolby).

\section{Theoretical framework}

Domestic science borrowed the word "image" from the English language, which in translation into Russian means 'pattern' (Explanatory Dictionary of the Russian Language, 2007: 297). Concretizing the concept of image, E.S. Kubryakova gives the following definition to this term, "image is a pattern that for one reason or another is intended to replace a real object or to represent a person or some other entity (from the character and appearance of a person up to the state and other power structures) in the eyes (perception) of other people" (Kubryakova, 2008: 9).

The work of A.V. Chepkasov analyses the semantically close terms "image", "pattern", "stereotype", "brand", "reputation", the semantic analysis of which allowed the author to highlight the specific components of each of the terms and establish that the image, being a type of a pattern, is formed from tendentious sources and is capable of leading to a change, clarification of the image, as well as its evaluation (Chepkasov, 2018b). In other words, the image is not static, it is formed in the consciousness of a person and, being influenced from the outside, can receive a different form of reflection of objects and phenomena of the surrounding reality in the consciousness of people. The leading task of imageology is the effective formation of the image of someone / something, image management.

Based on the term "image", the scientific literature formulated the terms "personality image", "brand image", "organizational image", "regional image", etc. Each of the varieties of image is characterized by a set of components, attributes ... It is important for us to understand the term "image of the region", interpreted as a stereotyped image in the mass conscious- 
ness, in which "the ideas of people about the socio-cultural, historical, socio-economic, political and other features of a given territory are merged together. At the same time, the subjective idea of each person about the region can be formed both on the basis of specific personal impressions, and indirectly, from materials of the mass media, literary and cinematic sources, based on eyewitness accounts, rumours and conjectures" (Vasilenko, 2012).

The importance of image policy at the regional level is evidenced by a number of political, economic, and cultural studies (Andrianova, 2009; Vazhenina, 2006; Vasilenko, 2012; Grinev, 2009; Dobrikova, 2012; Eremeev, 2009 and others). Proceeding from the fact that the image of someone / something is formed at the expense of linguistic (speech) means, linguistic works occupy a special place among works on imageology (Gorbunova, 2015; Savelyeva, Melnik, 2019; Pashkin, 2012; Prokhorov, 2013; Sushnenkova, 2011; Chepkasov, 2018a and others), developing the theory of linguoimageology (Kubryakova, 2008). Linguoimageological works can include those which study the speech portrait, linguistic personality, speech behaviour, and linguocultural type.

Securing a place for philological knowledge in imageology, which is an actively developing scientific field, linguoimageology solves the problem of the force of the texts of public and media discourses influencing the formation of a positive image of objects (animate and inanimate), including a specific territory, in the minds of the population. Thus, linguoimageology is a direction characterized by interdisciplinarity, the tasks of which include the study and development of technologies for creating the image of someone / something through the use of linguistic means that effectively influence the creation of a positive image of an object.

\section{Problem statement}

In the future, our research is aimed at a linguistic study of the image of one of the oldest cities in Siberia - Krasnoyarsk. In addition to cultural, socio-economic, historical features, the image of a territory is formed by iconic objects. Among other things, the tasks of the study included identifying these iconic objects. For this purpose, the authors carried out an online survey, which took into account the opinion of both Krasnoyarsk residents and residents of other cities (Bratsk, Irkutsk, Kemerovo, Moscow, St. Petersburg). The respondents had to answer the following question: Which city site do you associate Krasnoyarsk with? The survey involved 85 people, $50 \%$ of whom were residents of Krasnoyarsk, the rest were representatives of other cities. It was found that, among other things, $62.4 \%$ (53 out of 85 ) respondents associate Krasnoyarsk with Stolby Nature Reserve, which determined the choice of the object for the analysis that is the existing image of Stolby Nature Reserve.

Stolby is a favourite place for active recreation of Krasnoyarsk citizens, as well as a place of pilgrimage for city guests, as evidenced by beautiful photographs and rave reviews of tourists in social networks. The administration of the national park, with the support of the city authorities, is working on the improvement of the territory of the reserve, creating zones of comfortable free outdoor recreation, which even more attracts the attention of visitors to the site. All this works to form the image of Stolby. At the same time, if in the regional picture of the world the image of Stolby National Park occupies a leading position, then this cannot be said about the all-Russian and global worldviews. In this regard, in addition to studying the experience of developing the image of world-famous regional sites and its application for promoting lesser-known sites, it is necessary to analyse the linguistic mechanisms that have the greatest impact on consciousness in the process of improving the image of a regional site.

The purpose of this work is to model the image of one of the iconic objects of the city of Krasnoyarsk that is Stolby National Park, based on its exclusive properties.

Explanatory dictionaries of the modern Russian language and public texts about Stolby were used as the research material. In total, 40 texts were involved in the study, taken by a continuous sampling method from the official sites of the regional media in Krasnoyarsk (Vesti Krasnoyarsk, NGS24, Prima, TVK 
Krasnoyarsk), from federal news channels (Russia 1, Channel One, NTV, REN TV, RIA novosti, Russia 24: FEDERAL NEWS), from tourist websites (Sim Sim, Tripster, Tour Operator in Siberia, Sayan Koltso, Turister) and directly from the official website of the national park.

The following tasks were identified as the leading ones: in the course of the linguistic analysis of the texts under consideration, to determine the components of the concept of Stolby, to build a frame-type model, revealing the missing characteristics of the parameters of this model in publicistic texts; to establish what types of estimated values prevail in the texts about Stolby and what tropes are more often used in creating a positive image of the object under study.

\section{Methodology}

The work is carried out in the mainstream of cognitive linguistics, more precisely, its sub-section that is linguistic conceptology, whose tasks include the study of language as a means to access the content of concepts and as a means to model them. From the point of view of I.A. Sushnenkova, in addition to the marketing approach, the use of a lingo-cognitive approach to analysing the image of the region allows getting a multifaceted idea of the image of the region, revealing its implicit characteristics (Sushnenkova, 2011).

The study adopted the provisions developed in the field of linguistic conceptology, concerning the essence of concepts that allow storing knowledge about the world and are building elements of the conceptual system (Kubryakova et al., 1996) and knowledge structures, namely frames, organized around a certain concept (Babushkin, 1996; Dyck Wang, 1989).

The main methods were conceptual analysis, involving the description of concepts through the study of vocabulary definitions and contexts; semantic analysis of estimated values (according to the classification by N.D. Arutyunova), frame modelling of the concept.

Additional methods of the analysis were online questioning, quantitative calculation, elements of linguo-stylistic analysis of the text.

\section{Discussion of the results \\ 1. Content of the concept of Stolby National Park}

The name of the investigated object Stolby National Park - in addition to the direct name (Stolby), includes a hyponym (national park). I.A. Zatsepina, when describing the concept, offers not to be limited to direct nominations and to identify "all the nominative field of the concept available to the researcher, including the nominations of the varieties of the concept denotation (hyponyms), and the names of various individual features of the concept that are found in different situations when discussing it" (Zatsepina, 2007: 36). The researcher pays attention to the fact that "the most frequently nominated hyponyms are the most typical representatives of the concept in communication, the most frequently nominated features are the most striking features of the concept discussed in communication" (Zatsepina, 2007: 36). Taking this into account, we have identified the nominative fields National Park and Stolby as independent concepts.

The content of the concept National Park (this is the official status of Stolby Reserve) was obtained through the analysis of dictionary entries, including the following meanings:

1) natural territory with little disturbed landscape;

2) protected area;

3) large area;

4) containing natural complexes;

5) there are works to restore landscapes;

6) there are works to preserve rare and endangered species of plants and animals;

7) it is open to regulated visits;

8 ) it is intended for research, cultural and educational purposes;

9) nature reserve.

Among the varieties of the denotation of the concept National Park, there are some nouns standing out: territory, area, reserve. The names of individual features of this concept are recorded: natural, with little disturbed landscapes, protected, containing natural complexes, open for regulated visits, intended for research, cultural and educational purposes. 
To determine the content of the concept Stolby, we have studied 40 texts in detail. As a result of the analysis, sixteen objects were identified that are subject to language interpretation (assessment) (they also constitute the content of the defined concept): the reserve's birthday, the status of Stolby, free admission, landscaping, hiking trails, attendance, the availability for people with different abilities, sightseeing, events, rest, air, forest, rare species of plants and animals, nominations of rocks, protection, danger. Thus, 1 text out of 40 is devoted to the problem of vandalism, 2 texts - to the description of plants, 3 texts - to the reserve's birthday, the status of Stolby (national park or reserve), the availability of free admission per each. The diversity of fauna, the quality of the air (fresh, mountainous), the improvement of the reserve and hiking trails are mentioned in 4 texts in each case. Much more attention in media texts is paid to active attendance of the reserve (6 texts out of 40), its accessibility for old people and people with disabilities ( 7 texts out of 40), active rest (10 texts out of 40), the name of rocks (11 texts out of 40). The most frequent topics of the reviewed texts were messages about events organized in the reserve (12 texts out of 40 ), information about the protection of the territory of Stolby (13 texts out of 40), the topic "Stolby is a landmark" (also 13 texts out of 40) and possible dangers (14 texts out of 40).

When comparing the concepts National Park and Stolby, it was revealed that the content of the latter included a number of substantive components of the first that is generic concept, namely a protected area open to the public, peculiarities of flora and fauna.

The specific elements of the concept National Park are the location of the reserve on a large territory, its assignment for research, cultural and educational purposes, work on the conservation of rare and endangered species of plants and animals, as well as regulated visits.

The concept Stolby, in turn, is characterized by a different range of individual components, pragmatically significant for tourists: sightseeing, active lifestyle, free admission, accessibility for people with disabilities and old people, danger.
Taken together, these elements form the concept of Stolby National Park.

\section{Frame model of the concept of Stolby National Park}

In the theory of frames, the accepted point of view is that the cognitive structures of knowledge (frame, slot, mental image, etc.) organize a certain concept. "... Frames are a more or less conventional and therefore can define and describe that what is "characteristic" or "typical" of a given society (Dyck Wang, 1989: 16). The frame-based vocabulary organization is fundamentally different from other methods of vocabulary grouping. The basis for systematization is the mental model of a fragment of reality. By grouping lexical units, the researcher moves from the cognitive level to the linguistic level (Pleshakova, 1998: 9).

M. Minsky defined frame (taken from English and transliterated into Russian) as the structure of linguistic knowledge, organized around a certain concept, where information of different types is associated. “... A person, trying to learn a new situation for himself or take a new look at already familiar things, chooses from his memory some data structure (image), which we call a frame, so that by changing individual details in it to make it suitable for understanding a wider class of phenomena or processes" (Minsky, 1979: 7). According to M. Minsky, a person possesses a set of frames for different types of activity, for characterizing and assessing the environment and the conditions of his existence. These frames and the mechanisms of their interconnection are formed and developed during a person's life. The elements of the frame are slots (or terminals in the terminology of M. Minsky); they are intended to concretize any one aspect of the frame by filling it with "characteristic examples or data" (Minsky, 1979: 7).

The frame model of the concept Stolby National Park provides for 3 characterizing parameters: conceptual, pragmatic and evaluative. Let us present this model in a table. The table cells contain the semantic components identified from the analysed texts and dictionary definitions. The column Evaluative 
Table. Frame of the concept Stolby National Park

\begin{tabular}{|c|c|c|c|c|}
\hline \multirow{2}{*}{ Slot name } & \multirow{2}{*}{ Slot feature } & \multicolumn{3}{|c|}{ Parameter } \\
\hline & & conceptual & pragmatic & evaluative \\
\hline 1 & 2 & 3 & 4 & 5 \\
\hline \multirow[t]{9}{*}{ Territory } & \multirow[t]{3}{*}{ Ecosystem } & site & $\begin{array}{l}\text { Conservation of rare } \\
\text { and endangered plant } \\
\text { and animal species }\end{array}$ & $\begin{array}{l}\text { Stolby is the icon of } \\
\text { Krasnoyarsk! } \\
\text { Stolby is a pearl of Si- } \\
\text { berian nature }\end{array}$ \\
\hline & & air & $\begin{array}{l}\text { people go to Stolby } \\
\text { to breathe clean air }\end{array}$ & $\begin{array}{l}\text { Over half a million peo- } \\
\text { ple go to Stolby for } \\
\text { clean air every year. }\end{array}$ \\
\hline & & forest & & Stolby is the lungs of Siberia. \\
\hline & Area & large & & \\
\hline & Landscape & Little disturbed & $\begin{array}{l}\text { Restorative works } \\
\text { are underway }\end{array}$ & \\
\hline & \multirow[t]{3}{*}{ Open } & \multirow[t]{3}{*}{ Actively visited } & Regulated visits & $\begin{array}{l}\text { The reserve reminds that } \\
\text { from May } 1 \text {, visits to the } \\
\text { buffer zone are limited. }\end{array}$ \\
\hline & & & free entry & \\
\hline & & & $\begin{array}{l}\text { accessibility for old } \\
\text { people and people } \\
\text { with disabilities }\end{array}$ & $\begin{array}{l}\text { Every weekend hundreds of } \\
\text { Krasnoyarsk residents go for } \\
\text { a walk to Stolby reserve. }\end{array}$ \\
\hline & protected & $\begin{array}{l}\text { protected by the } \\
\text { state and UNESCO }\end{array}$ & & \\
\hline \multirow[t]{3}{*}{ Assignment } & \multirow[t]{2}{*}{ reserve } & \multirow[t]{2}{*}{ specific purposes } & Research & \\
\hline & & & $\begin{array}{l}\text { organization and } \\
\text { conduct of cul- } \\
\text { tural and educa- } \\
\text { tional events }\end{array}$ & $\begin{array}{l}\text { Stolby is a must-vis- } \\
\text { it for everyone! }\end{array}$ \\
\hline & rest & active & $\begin{array}{l}\text { sports tourism, } \\
\text { including rock } \\
\text { climbing }\end{array}$ & $\begin{array}{l}\text { In the second half of the } \\
19^{\text {th }} \text { century, a unique } \\
\text { movement «stolbism» was } \\
\text { born here. Stolbists are } \\
\text { people who are passion- } \\
\text { ate about rock climbing. }\end{array}$ \\
\hline $\begin{array}{l}\text { Infra- } \\
\text { structure }\end{array}$ & improvement & & & $\begin{array}{l}\text { The state inspectors of the na- } \\
\text { tional park have done a great } \\
\text { job during recent two months. }\end{array}$ \\
\hline Vandalism & $\begin{array}{l}\text { there are citizens } \\
\text { who do appre- } \\
\text { ciate what is } \\
\text { done for them }\end{array}$ & gazebos are broken & & \\
\hline \multirow[t]{3}{*}{ Danger } & $\begin{array}{l}\text { remoteness from } \\
\text { the transport } \\
\text { highway }\end{array}$ & $\begin{array}{l}\text { in case of emergen- } \\
\text { cy, help will not be } \\
\text { received immediately }\end{array}$ & & How to make Stolby safe? \\
\hline & wild animals & $\begin{array}{l}\text { bears come out } \\
\text { to hiking trails }\end{array}$ & $\begin{array}{l}\text { you need to } \\
\text { be careful }\end{array}$ & $\begin{array}{l}\text { Bears are awake in Stol- } \\
\text { by. Be careful! }\end{array}$ \\
\hline & wild forest & you can get lost & & $\begin{array}{l}\text { Alarming reports come from } \\
\text { there almost every week- } \\
\text { end. Rescuers on a stretcher }\end{array}$ \\
\hline
\end{tabular}


Continuation Table

\begin{tabular}{|l|l|l|l|l|}
\hline 1 & \multicolumn{1}{|c|}{2} & \multicolumn{1}{|c|}{3} & \multicolumn{1}{c|}{5} \\
\hline & & & & $\begin{array}{l}\text { carry out those who have } \\
\text { twisted their legs, remove } \\
\text { those who cannot go down } \\
\text { from the rocks, look for those } \\
\text { who have lost their way. }\end{array}$ \\
\hline & steep cliffs & & $\begin{array}{l}\text { Blood and rocks: the loud- } \\
\text { est tragedies of Stolby }\end{array}$ \\
\hline $\begin{array}{l}\text { Onomas- } \\
\text { ticon }\end{array}$ & $\begin{array}{l}\text { dead trees in } \\
\text { the forest } \\
\text { of the reserve } \\
\text { (rocks, streams, } \\
\text { trails, etc.) have } \\
\text { proper names }\end{array}$ & & $\begin{array}{l}\text { Fallen dead trees regu- } \\
\text { larly damage the national } \\
\text { park by breaking its in- } \\
\text { frastructure objects }\end{array}$ \\
\hline
\end{tabular}

Parameter contains fragments of contexts containing the evaluation.

Frame modelling allows highlighting the gaps in the texts about any object. Unfilled cells of the table indicate that we did not find a display of this or that parameter in the analysed texts and dictionary definitions. Thus, the pragmatic parameter does not reveal all slots. For example, the "danger" slot, named by the respondents as important (see the results of the online survey above), contains practically no pragmatically significant characteristics in the texts. Let us emphasize that it is the pragmatic parameter, along with the evaluative one, that is of leading importance for the formation of the image of an object, since these parameters with the help of specific signs demonstrate the consolidation in the language of what is important for a person, and the effect of these signs on people.

Let us dwell separately on the characteristics of the evaluative components recorded in the texts about Stolby.

\section{Types of estimated values}

in media texts about Stolby

\section{and ways of expressing them}

Any journalistic text contains an evaluative component - explicit or implicit, which contributes to the interpretation of the text of actual information by the author and the introduction of the author's interpretation into the consciousness of the addressee. The latter is one of the tasks of image makers. U. Eco noted that "(except for the weather forecast) objective information does not exist and cannot exist. Even with pedantic separation of the commentary from the message, the selection of messages and their placement on the page itself includes an implicit judgment" (Eco, 1998: 48-50).

Due to the fact that the category of evaluation is an important element of the journalistic text, it is necessary to determine the concept of evaluation and its types. Since the evaluation in the media text is socially conditioned, we agree with the definition of A.A. Tertychny, who noted that "evaluation is the attitude of the subject of evaluation (a journalist or any other person) to the subject being evaluated. This attitude arises as a result of comparing the subject of evaluation with certain criteria, which can be needs, interests, ideals, norms, patterns, standards, etc." (Tertychny, 2000: 214).

In our opinion, N.D. Arutyunova offers an exhaustive classification of estimated values, highlighting two types of them: general evaluative and specific evaluative values. "The first type is realized by the adjectives good and bad ... The second group is more extensive and 
diverse. It includes values that evaluate one aspect of an object from a certain point of view. $<\ldots>$ Groups of specific estimates are significantly different from each other in the range of compatibility, i.e. by what types of objects they are able to qualify" (Arutyunova, 1988: 75). Since this work examines the evaluations of individual elements of the concept Stolby, we are interested in the classification of specific evaluative values, which includes three groups of different categories: sensory evaluations (sensory-gustatory, psychological), sublimated (aesthetic and ethical) and rationalistic (utilitarian, normative, teleological).

The first group (sensory evaluations) is characterized by a connection "with sensations, sensory experience - physical and mental. They orient a person in the natural and social environment, contributing to his accommodation, the achievement of comfort ... Evaluation stems directly from the feeling that a person experiences, regardless of will and self-control" (Arutyunova, 1988: 76). Thus, sensory-gustatory evaluations express descriptions of pleasant / unpleasant, tasty / not tasty, etc. Psychological evaluations, in which a step is made towards rationalization, understanding the motives of the evaluation, are divided into intellectual (exciting, inspiring) and emotional (sad, joyful).

The second group (sublimated evaluations) "constitutes the core of a person's spiritual beginning, modelled vertically in accordance with his bodily orientation ... This group ... is not indifferent to the concept of an archetype a norm, a pattern, an example, potential requirements for an object" (Arutyunova, 1988: 76). This group includes aesthetic evaluations, which are obtained as a result of the synthesis of sensory-gustatory and psychological assessments (beautiful - ugly, pleasant - unpleasant, etc.), and ethical evaluations (moral - immoral, ethical - unethical, etc.) etc.).

The third group of axiological values (rationalistic) is associated with the practical activity of a person. "Their main criteria are physical and mental benefit, focus on achieving a specific goal, performance of a certain function (including the one for which this subject is intended), compliance with an established standard" (Arutyunova, 1988: 77). This group includes utilitarian evaluations (useful - harmful, favourable - unfavourable), normative (right - wrong, correct - incorrect) and teleological (effective - ineffective, expedient - inexpedient, successful - unsuccessful).

As a result of the analysis of the texts, it was revealed that the components of the concept Stolby are most represented through sensory and rationalistic evaluations. Thus, the most frequent estimated values belong to the psychological category (in 24 texts out of 30) and, as a rule, are combined with ethical category (in 8 texts), normative category (in 8 texts), sensory-gustatory category (in 4 texts), theological category (in 3 texts) and aesthetic category (in 2 texts). Here is an example of a context in which there is a combination of different types of evaluation.

"It was proposed to build a 4-kilometer cable car in Stolby Nature Reserve for 2 billion roubles. According to officials, such an object will help attract more tourists to the city and increase the availability of the reserve... According to the head of the regional tourism agency Yulia Verkhushina, the attendance of Stolby is constantly growing. Over the past 5 years, the influx of tourists has doubled - in 2018, about 800 thousand people visited the reserve. Therefore, one of the main sites of Krasnoyarsk needs a global update, according to the tourism agency ... In order to implement such global plans, in addition to the construction of a cable car, it will be necessary to equip $67 \mathrm{~km}$ of hiking trails, develop a unified navigation, extend the route of the city electric train, and provide stable cellular communication throughout the entire tourist area. According to the authors of the concept, the construction of the cable car may require about 2 billion roubles..." (TVK Krasnoyarsk). This text presents a psychological emotional evaluation (desired improvements are taking place), utilitarian (such changes are favourable for Stolby and its visitors) and ethical (good deeds are being done - the infrastructure of the reserve is developing) evaluations.

The number of estimated values corresponding to the psychological category is $80 \%$ of all expressed. Ethical and normative 
categories are the least represented. They are expressed in the amount of $26.7 \%$ of the total allocated estimated values. The least common were sensory-gustatory (13.3\%), theological $(10 \%)$ and aesthetic categories $(6.7 \%)$.

Evaluation in media texts is realized through tropes, which in the texts under consideration constitute 41 linguistic units. The most frequent trope in the considered media texts are metaphor, rhetorical exclamation and epithet. The metaphor occurs 11 times and thus makes up $26.8 \%$ of the total number of tropes (Stolby is a miracle, Stolby is the icon of the city, a pearl of Siberian nature, soul and lungs of Siberia, a reserved core). Rhetorical exclamation was found in 8 texts, which accounted for $19.5 \%$ of all tropes. Media texts contain such exclamations as "To come to Krasnoyarsk without visiting Stolby means not getting a complete impression of the capital of the region!", "90 years ago, the famous Stolby Reserve was founded!", "Let's leave the Stolby clean!" etc. The epithet complements the general picture of the text and is found only 5 times: its implementation is $12.2 \%$ (unlimited possibilities, bizarre rocks, dear visitors, touching words of gratitude).

The least common were such tropes as repetition, rhetorical question, hyperbole, personification and antithesis. Each of these means of artistic expression was encountered 3 times, which is only $7.3 \%$ of the total number of tropes. The least frequently used trope was metonymy (4.8\%). For example, "The emergency medical aid point has started working" or "Even if the reserve, for some malicious intent, would have already wanted to introduce this payment, using the status of the national park, it would still not have been able to do so. But the reserve definitely does not have such a desire".

All identified means of artistic expression were used by the authors of the texts not only for the transmission of information, but also for the purpose of its interpretation. It is important to note that among the 40 reviewed texts, there were no negative evaluations characterizing the iconic city object itself, as well as the tourists staying at Stolby during the trip.

However, we came across texts with negative information (There is a problem in the re- serve, namely damage to fir stands by the Ussuriysk beetle, which is a forest pest (Prospect Mira); The owner of the land in the protected zone of Stolby reserve cut down a section of the reserved forest (KGS.RU Krasnoyarsk city site). News stories often tell about incidents at Stolby, when tourists are injured or, having climbed onto the rocks, cannot get down from them. But such texts, as a rule, carry positively perceived information, because people who are in an unpleasant situation, get help, "They climbed onto the Third Stolb, took a lot of photographs of themselves and the surroundings, but could not go down on their own... The Emergencies Ministry specialists arrived at the site promptly, immediately deployed their special equipment and took the unlucky climbers down". Komsomolskaya Pravda. Krasnoyarsk).

The number of texts about Stolby containing negative information has increased in connection with the announcement of a pandemic due to COVID-19. But this information concerns, first of all, the forced measures taken by the police and the administration of the national park (Krasnoyarsk tourists have to be expelled from Stolby with a scandal. Being in the territory is a violation of the special protection regime and entails a fine. Newslab.ru), as well as the appearance of stray dogs on the territory of the reserve (A large number of complaints about stray dogs come to the administration of Stolby National Park. Most often, dogs are found along the road from the Laletino cordon to the Pereval. The press service of the park says that the invasion of the dogs is connected with the opening of a part of the territory for citizens to visit. Visitors bring food with them and "compassionate" ones leave edible remains that attract dogs. AIF. Krasnoyarsk).

\section{Conclusion}

The study presents the content of the concept Stolby National Park, whose components' multidimensionality is demonstrated by the frame model of this concept presented in the work.

The model includes three characterizing parameters, namely conceptual, pragmatic and evaluative. The analysis of empirical material showed that the pragmatic aspect, which is most 
significant for the population, is not sufficiently represented in the media texts. The evaluative component is presented in the studied texts, however, evaluativity is not so frequent and the means of linguistic representation of the evaluation are not diverse. The predominantly positive interpretation of information about the concept of Stolby is achieved through psychological private evaluative values through such tropes as metaphor, rhetorical exclamation and epithet.

The analysed texts implement the leading components (according to the classification of A.V. Chepkasov (Chepkasov, 2018b)) of the concept of Stolby National Park's regional image. Thus, the texts record the individualization of the object (a regional landmark), the symbolism (the reserve has a name recognizable outside the region; photographs of rocks are widespread - visual signs with specific names that is verbalization of signs), the stability of a number of ideas about the reserve, multidimensionality (image reserve, which is available in the minds of people and formed by means of texts, consists of a list of slots and their characteristics that make up the frame model). Such components as flexibility (variability of the image), fundamental ambiguity (the image is subjective) seem to be insignificant for the object studied in the work, since the existing image of Stolby National Park is quite stable in the minds of the local population. Stability is inherent in the image of most natural objects, for example, such as Lake Baikal, Ergaki or Sheregesh, etc., the beauty of which delights tourists.

We consider the following to be significant for strengthening the image positions of Stolby National Park: in texts about Stolby, it is necessary to mention more often the improvement of the infrastructure of hiking trails in the reserve (pragmatic aspect) using evaluative linguistic constructions. It was the pragmatic characteristics that turned out to be paramount for the respondents during the online survey. It seems necessary to create media texts on rare and endangered plant and animal species in the reserve. Such information, presented with the help of linguistic means of expression, will not only support the image of Stolby National Park, but also attract tourists interested in flora and fauna to the reserve.

In the future, we plan to carry out a study of other sites in Krasnoyarsk (the legendary Communal Bridge across the Yenisei, Bobrovy Log fun park, Krasnoyarsk Opera and Ballet Theatre, Siberian Federal University), which, according to the results of an online survey, among others, were recognized as significant for the region and the city.

\section{References}

Andrianova, A.A. (2009). Imidzh i strategii innovatsionnogo razvitiia regiona: politiko-tekhnologicheskii aspekt: dis. ... kand. polit. nauk: 23.00.02 [Image and strategies of regional innovative development: political and technological aspect: PhD thesis]. Krasnodar, Publishing house of Kuban State University.

Arutyunova, N.D. (1988). Tipy iazykovykh znachenii. Otsenka, sobytie, fakt [Types of linguistic values. Evaluation, event, fact]. Moscow, Nauka, 338 p.

Babushkin, A.P. (1996). Tipy kontseptov v leksiko-frazeologicheskoi semantike iazyka [Types of concepts in the lexico-phraseological semantics of the language]. Voronezh, Voronezh University Publishing House, $104 \mathrm{p}$.

Chepkasov, A.V. (2018a). Modelirovanie imidzha Kuzbassa po dannym SMI [Modelling the image of Kuzbass according to media data]. In Lingvokul'turologiia [Linguoculturology], 2, 36-40.

Chepkasov, A.V. (2018b). Imidzh regiona v rechi regional'nogo lidera i massovoi kommunikatsii (genezis $i$ struktura) [Image of the region in the speech of a regional leader and mass communication (genesis and structure)]. Moscow, Pushkin State Russian Language Institute, 352 p.

Gorbunova L.I. (2015). Baikal kak kontseptual'nyi element kontseptosfery sibiriaka [Baikal as a conceptual element of the Siberian concept-sphere]. In Vestnik Tomskogo universiteta. Filologiia [Bulletin of Tomsk University. Philology], 1(33), 5-15. 
Grinev, I.V. (2009). Rol' natsional'noi rossiiskoi kul'tury v formirovanii mezhdunarodnogo imidzha strany: avtoref. dis. ... kand. filos. Nauk: 24.00.01 [The role of national Russian culture in the formation of the international image of the country: synopsis of PhD thesis]. Moscow.

Deyk, vann T.A. (1989). Freimy znanii i ponimanie rechevykh aktov / Per. s angl. M. A. Dmitrievoi [Knowledge frames and understanding of speech acts. Translated from English by M.A. Dmitrieva]. In Iazyk. Poznanie. Kommunikatsiia: Sb. rabot [Language. Cognition. Communication: collection of works]. Moscow, 12-40.

Dobrikova, A.A. (2012). Imidzh regiona v sotsiokul'turnoi kommunikatsii (na primere Cheliabinskoi oblasti): avtoreferat dis. ... kand. kul'turologi: 24.00 .01 [Image of the region in socio-cultural communication (based on the example of the Chelyabinsk region): synopsis of PhD thesis]. Chelyabinsk, $24 \mathrm{p}$.

Eco, U. (1998). O presse [On the Press]. In piat' esse na temu etiki [Five Essays on Ethics]. Symposium, $48-50$.

Eremeev, S.N. (2009). Formirovanie imidzha regiona kak instrumenta upravleniia ego razvitiem: diss. ... kand ekonom. Nauk: 08.00.0 [Formation of the image of the region as a tool for managing its development: PhD thesis]. Moscow, $197 \mathrm{p}$.

Frolova, E.V. (2007). Kommunikativnye strategii formirovaniia imidzha regional'nogo lidera $v$ elektronnykh SMI: dis. ... kand. filol. nauk: 10.02.01 [Communicative strategies for forming the image of a regional leader in e-media: PhD thesis]. Omsk, 2007.

Kubryakova, E.S. (2008). K opredeleniiu poniatiia imidzha [On the definition of the concept of image]. In Voprosy kognitivnoi lingvistiki [Issues of cognitive linguistics], 1(014), 5-11.

Kubryakova, E.S., Demyankov V.Z., Pankrats Yu.G., Luzina, L.G. (1996). Kratkii slovar' kognitivnykh terminov [A concise dictionary of cognitive terms]. Moscow, Philological Faculty of Lomonosov Moscow State University, $245 \mathrm{p}$.

Minsky, M. (1976). Freimy dlia predstavleniia znanii: Per. s angl. O.N. Grinbauma. Pod red. Doktora tekhn. nauk F.M. Kulakova [Frames for knowledge representation. Translated from English by O.N. Grinbaum. Edited by Doctor F.M. Kulakov]. Moscow, Energiia, 152 p.

Pashkina, T.A. (2012). Poniatie «imidzh territorii» v sovremennoi nauke i praktike [The concept "image of the territory" in modern science and practice]. In Izvestiia Saratovskogo universiteta [Bulletin of Saratov University], 2. Saratov, 63-66.

Petrova, E.A. (2007). Imidzh kak faktor produktivnoi politicheskoi kommunikatsii [Image as a factor of productive political communication]. In Korporativnaia imidzheologiia [Corporate imageology]. Moscow, RITS “RUSAKI”, 48-56.

Pleshakova, A.V. (1998). Issledovanie freimov "proisshestvie» na materiale russkikh i angliiskikh gazetnykh tekstov zhanra «informatsionnoe soobshchenie»: avtoref. diss. ...kand. filol. nauk: 10.01.19 [Research of frames "incident" based on the material of Russian and English newspaper texts of the genre "information message": synopsis of PhD thesis]. Saratov, $22 \mathrm{p}$.

Potemkina, O.F. (2008). Imidzh politicheskogo lidera [The image of a political leader]. Moscow, Publishing house of Moscow State University of Culture and Arts.

Prokhorov, A.V. (2013). Spetsifika lingvisticheskogo modelirovaniia imidzha [Specificity of linguistic modelling of the image]. In Vestnik TGU [Bulletin of Tomsk State University], 9(125), 254-257.

Savelyeva, I.V., Melnik, N.V. (2019). Obraz kuzbasskogo gornolyzhnogo kurorta Sheregesh v diskurse internet-otzyvov [The image of the Kuzbass ski resort Sheregesh in the discourse of online reviews]. In Zhurnal Sibirskogo federal'nogo universiteta. Seriia: Gumanitarnye nauki [Journal of Siberian Federal University. Series: Humanities], 12(1), 137-154.

Sushnenkova I.A. (2011). Lingvokognitivnoe issledovanie regional'nogo imidzha (na primere Omskoi oblasti): Avtoref. dis. ... kand. filol. nauk: 10.02.19 [Linguocognitive study of the regional image (based on the example of the Omsk region): synopsis of PhD thesis]. Kemerovo, Kemerovo State University, $25 \mathrm{p}$.

Tertychnyi, A.A. (2000). Zhanry periodicheskoi pechati: Uchebnoe posobie [Genres of periodicals: Textbook]. Moscow, Aspect Press, 312 p. 
Tolkovyi slovar' russkogo iazyka s vkliucheniem svedenii o proiskhozhdenii slov. Otv. red. N.Iu. Shvedova [Explanatory dictionary of the Russian language with the inclusion of information about the origin of words. Publishing editor. N.Iu. Shvedova]. Moscow, 1175 p.

Vazhenina, I.S. (2006). Imidzh kak konkurentnyi resurs territorii [Image as a competitive resource of the territory]. In Marketing $v$ Rossii i za rubezhom [Marketing in Russia and abroad], 6, 47-64.

Vasilenko, I.A. (2012). Sovremennyi imidzh rossiiskikh regionov: problemy formirovaniia [The modern image of Russian regions: problems of formation]. In Zhurnal'nyi klub Intelros «Mir i politika» [Intelros magazine club "World and Politics"], 12. Available at: www.intelros.ru/readroom/mir-i-politi$\mathrm{ka} / \mathrm{m} 12-2012 / 17323$-sovremennyy-imidzh-rossiyskih-regionov-problemy-formirovaniya.html (accessed 07/27/2020)

Volkova I.V., Klimenko V.V., Safrazian L.T. (1997). Imidzh politicheskikh liderov Rossii v SMI [The image of Russia's political leaders in the media]. In Mir Rossii [World of Russia], 3, 43-74.

Zatsepina, E.A. (2007). Nominativnoe pole kak ob"ektivatsiia kontsepta [Nominative field as objectification of the concept]. In VESTNIK VGU. Seriia: Filologiia. Zhurnalistika [Bulletin of Voronezh State University. Series: Philology. Journalism], 1, 36-38.

\title{
Концепт «Национальный парк “Красноярские Столбы”" \\ в аспекте лингвоимиджелогии
}

\author{
И.В. Евсеева, И.С. Жмакина \\ Сибирский федеральный университет \\ Российская Федерация, Красноярск
}

\begin{abstract}
Аннотация. Рассматривается концепт «Национальный парк "Красноярские Столбы”» в аспекте теории лингвоимиджелогии, в задачи которой входит изучение и разработка технологий создания имиджа кого-, чего-либо за счет применения языковых средств, эффективно влияющих на создание положительного образа объекта.

Ведущая цель работы заключается в моделировании образа национального парка на основе эксклюзивных свойств этого объекта. В ходе лингвокогнитивного анализа эмпирического материала (публицистические тексты о заповеднике) выявлены составляющие исследуемого концепта; построена модель фреймового типа, предусматривающая понятийную, прагматическую и оценочную характеристику слотов фрейма; определены типы оценочных значений, преобладающие в текстах о заповеднике; установлена частотность языковых средств - художественных тропов, используемых в создании положительного образа изучаемого объекта.

Выявленные составляющие концепта «Национальный парк "Красноярские Столбы”» были положены в основу фреймовой модели, создание которой позволило выделить лакуны, имеющиеся в современных текстах о заповеднике.

Разработанная методология может быть применена к анализу имиджевой составляющей других знаковых региональных объектов. В исследовании предложены рекомендации по совершенствованию имиджа национального парка, что может быть учтено при создании новых текстов руководством заповедника и туристическими агентствами.
\end{abstract}


Ключевые слова: лингвоимиджелогия, лингвоконцептология, концепт, имидж, национальный парк «Красноярские Столбы», фреймовая модель концепта, типы оценочных значений, средства языкового выражения оценки.

Научная специальность: 10.00.00 - филологические науки. 